\title{
Failure to Induce Mucosal Disease in Cattle Persistently Infected with Bovine Viral Diarrhea Virus by Treatment with Adrenocorticotropic Hormone
}

\author{
By B. Larsson
}

\begin{abstract}
Larsson, B.: Failure to induce Mucosal Disease in Cattle Persistently Infected with Bovine Viral Diarrhea Virus by Treatment with Adrenocorticotropic Hormone. Acta vet. scand. 1988, 29, 1-8. - Recent research has shown that cattle that develop mucosal disease (MD) often, if not always, have been persistently infected with bovine viral diarrhea virus (BVDV) since birth. The purpose of the present study was to determine whether MD could be induced by immunosuppression of persistently BVDV-infected cattle. For that purpose, adrenocorticotropic hormone (ACTH) was injected intramuscularly, twice daily for 5 consecutive days in 4 persistently BVDV-infected cattle and in 3 control cattle. Before the ACTH treatment, the numbers of leukocytes, neutrophils and mononuclear cells (MNC) per litre of blood in BVDV-infected cattle were in the same range as in the controls. Similarly, the proportions of B cells, T cells, monocytes and Fc $\gamma^{+}$cells (cells with receptor for the Fc part of IgG) were the same in the 2 groups of animals. On the other hand, the proliferative response to mitogen stimulation of MNC obtained from the control animals was twice as high as the corresponding value of the persistently BVDV-infected cattle.

In all animals, ACTH treatment caused increased cortisol concentrations, leukocytosis, neutrophilia and decreased mitogen-induced lymphocyte stimulation. However, the MNC count and the proportions of B cells, T cells, $\mathrm{Fc} \gamma^{+}$cells and monocytes remained unaltered. In spite of the immunosuppression, indicated by the decrease in mitogen-induced lymphocyte stimulation. ACTH treatment did not provoke any clinical signs of MD in the persistently BVDV-infected cattle.
\end{abstract}

persistent BVDV infection; ACTH; mononuclear cell subpopulations; lymphocyte stimulation.

\section{Introduction}

Mucosal disease (MD) is distinguished by erosions of the mucosa of alimentary tract and by high mortality rates (Ramsey \& Chivers 1953), whereas bovine viral diarrhea (BVD) is characterized by diarrhea, leukopenia and subsequent recovery (Olafson et al. 1946). The causative agent of both the syndromes is the bovine viral diarrhea virus (BVDV). Whereas BVD is caused by a pri- mary infection with BVDV, the pathogenisis of MD is more complex. In 1968 Malmquist suggested that MD occurs in cattle which are persistently infected with and immunotolerant to BVDV; immunotolerance is established in the fetus during early pregnancy following a transplacental infection. This hypothesis has later been supported by results of other authors (Liess et al. 1974, Steck et 
al. 1980, Roeder \& Drew 1984, Brownlie et al. 1984).

From an immunological point of view, persistently BVDV-infected cattle have no or only low levels of antibodies to the agent. The infected animals have normal numbers of leukocytes as well as normal proportions of $\mathbf{B}$ and $\mathrm{T}$ lymphocytes (Bolin et al. 1985) but isolated lymphocytes respond poorly to mitogen stimulation (Roth et al. 1986). The weakened proliferation of their lymphocytes may be attributed to an increased suppressor activity, exerted by mononuclear cells (MNC) with receptor for the Fc part of IgG (Fc $\gamma^{+}$cells) (Larsson 1988).

Why persistently BVDV-infected cattle develop MD is not fully understood. Experimentally, MD can be provoked by infecting cattle which carry a non-cytopathic strain of the virus with a cytopathic strain of BVDV (Brownlie et al. 1984, Bolin et al. 1985). Mucosal disease may also develop after a mutation of the persistent infecting agent (Brownlie et al. 1986), but also other mechanisms may be involved. Colostrum-fed calves, seronegative to $\mathrm{BVDV}$, have after treatment with high doses of the immunosuppressive drug dexamethasone and subsequent inoculation with BVDV, developed a disease similar to MD (Shope et al. 1976). Therefore, it is possible that external stress and high cortisol levels may provoke MD. A direct approach to evaluate the effect of cortisol is to administer adrenocorticotropic hormone (ACTH). The purpose of the present study was therefore primary to investigate whether MD could be provoked in persistently BVDV-infected cattle by treating the animals with ACTH. Secondly, the effects of ACTH treatment on plasma cortisol (P-cortisol), total and differential leukocyte counts, and composition and function of blood mononuclear cells (MNC) were studied in persistently BVDV-infected cattle and compared with the effect of the same treatment in control animals.

\section{Materials and methods \\ Cattle}

The 4 persistently BVDV-infected cattle (nos. 1-4) used in the study were of Swedish Friesian breed (no. 1, aged 10 months) and of Swedish Red and White breed (no. 2, aged 15 months; nos. 3 and 4, both aged 3 years). The virus was detected in serum from the animals twice, 2 months apart, as described elsewhere (Larsson et al. 1988). The animals had no serum antibodies to the agent as determined by an indirect enzyme-linked immunosorbent assay (Juntti et al. 1987). Three control animals (nos. 5-7) were selected to match the BVDV-infected cattle nos. 1,3 and 4 with respect to age and breed. The controls were negative for BVDV isolation from serum but did have serum antibodies to BVDV.

\section{Experimental design}

The study was carried out during 2 periods, 1 month apart. During the first period, 2 persistently BVDV-infected cattle (nos. 1 and 2) and 1 control animal (no. 5) were subjected to ACTH treatment, while controls 6 and 7 were used as untreated controls.

In the second period the other 2 BVDV-infected cattle (nos. 3 and 4) and controls 6 and 7 were injected with ACTH, while animal no. 5 was used as an untreated control. Rectal temperature and clinical signs of disease were recorded daily during and 1 month following ACTH treatment.

\section{Blood samples and ACTH treatment}

Blood samples were taken by jugular vein puncture, 3 days and 1 day prior to ACTH treatment. The animals subjected to administration with ACTH (Acton prolongatum ${ }^{\otimes}$, Ferring, Malmö, Sweden) were given 60 
IE/100 kg of body weight intramuscularly twice daily ( 8 a.m. and 4.30 p.m.) for 5 consecutive days. The animals were bled at 11 a.m. on the second day (day 2), on the fourth day (day 4) during ACTH treatment, and again 2 days after completion of treatment.

Untreated controls were bled on the same occasions as the ACTH-treated animals.

\section{Blood analyses}

Total and differential leukocyte counts and determination of the level of cortisol in plasma (P-cortisol) were performed at the Dept. of Clinical Chemistry, Swedish University of Agricultural Sciences, Uppsala, Sweden, using standard methods. Briefly, the number of leukocytes was measured with a celloscope and differential counts were carried out on EDTA blood smears, stained with Giemsa's and May-Grünwald's solutions. The level of P-cortisol was determined by radio-immunoassay (Nyberg et al. 1988).

\section{Isolation of mononuclear cells from blood}

Mononuclear cells (MNC) were isolated according to the method of Bøyum (1968), modified for cattle as described by Johnson \& Morein (1977). Briefly, after centrifugation of heparinized blood on Ficoll-paque (Pharmacia Fine Chemicals, Uppsala, Sweden), the MNC were isolated from the interphase, washed three times in phosphate-buffered saline (pH 7.2) and resuspended in RPMI1640 growth medium, supplemented with $10 \%$ heat-inactivated fetal calf serum, 2 mmol/1 L-glutamine, $200 \mathrm{IU} / \mathrm{ml}$ penicillin and $200 \mu \mathrm{g} / \mathrm{ml}$ streptomycin (complete medium).

\section{Identification of blood MNC subpopula- tions}

The MNC were characterized by methods previously described for cattle (Johansson \&
Morein 1983, Fossum et al. 1985, Matsson et al. 1985). Briefly, B cells were detected by fluoresceinated $F\left(a b^{\prime}\right)_{2}$ fragments of rabbit antibodies to bovine IgM. T cells were identified as cells attaching the lectin Helix pomatia A hemagglutinin by an indirect immunofluorescence method. MNC with receptor for the Fc part of $\mathrm{IgG}(\mathrm{Fc} \gamma+$ cells $)$ were detected by rosette formation, using erythrocytes coated with IgG. Monocytes were identified as cells ingesting 3 or more latex beads after $20 \mathrm{~h}$ of incubation at $37^{\circ} \mathrm{C}$. The proportions of respective subpopulation were determined by counting 200 cells under a fluorescence microscope.

\section{Lymphocyte stimulation test}

The concentration of MNC was adjusted to $3 \times 10^{6}$ cells per ml complete medium. Equal volumes $(100 \mu \mathrm{l})$ of cell suspension and complete medium (control culture), or complete medium containing mitogen, were added per well to microtitre plates. The mitogens used were Concanavalin A (Con A) (Pharmacia Fine Chemicals, Uppsala, Sweden) $1 \mu \mathrm{g} /$ well and pokeweed mitogen (PWM) (Boehringer Mannheim, Mannheim, W. Germany) $1 \mu \mathrm{g} /$ well.

Each type of culture was set up in quadruplicate, incubated for 3 days at $37^{\circ} \mathrm{C}$, pulsed with $1 \mu \mathrm{Ci}{ }^{3} \mathrm{H}$-thymidine and reincubated for 1 day. The cells were harvested and the radioactivity measured. The results are expressed as mean counts per min (cpm) for each type of culture.

\section{Expression of results and statistical analysis} The pretreatment data were calculated as mean values of the 2 blood samples taken prior to ACTH treatment. The suppression of mitogen-induced lymphocyte proliferation during ACTH administration was calculated according to the formula: 
\% Suppression $=$
(1- $\left.\frac{\text { cpm during ACTH administration }}{\text { cpm before ACTH administration }}\right) \times 100$

Student's t-test was used for the statistical analysis. Data are expressed as means\pm S.E.M. unless otherwise indicated.

\section{Results \\ Clinical signs}

The animals appeared healthy and none had a rectal temperature above $39.2^{\circ} \mathrm{C}$ throughout the observation period.

\section{The level of P-cortisol}

In all animals the level of P-cortisol was below $20 \mathrm{nmol} / 1$ prior to ACTH treatment. The mean level of P-cortisol increased during the $\mathrm{ACTH}$ treatment to $230 \pm 16 \mathrm{nmol} / 1$ (day 2) and to $253 \pm 27 \mathrm{nmol} / 1$ (day 4) in the persistently BVDV-infected group. Similarly, the mean level of cortisol increased to $206 \pm 30 \mathrm{nmol} / \mathrm{l}$ (day 2) and to $210 \pm 17$ nmol/1 (day 4) in the ACTH-treated control group. Two days after completion of the ACTH treatment, the levels of P-cortisol reverted to their initial value. The level of $P$ cortisol remained below $20 \mathrm{nmol} / 1$ in the untreated group throughout the period.

\section{Total and differential leukocyte counts}

The total and differential leukocyte counts before, during and after ACTH treatment are shown in Fig. 1. Total numbers of leukocytes, as well as the numbers of neutrophils, were increased in blood, both from persistently BVDV-infected cattle and from controls during ACTH treatment, compared with the pretreatment data. Numbers of eosinophils fell during ACTH treatment to about half of the pretreatment value. The total number of MNC was not affected by ACTH treatment.

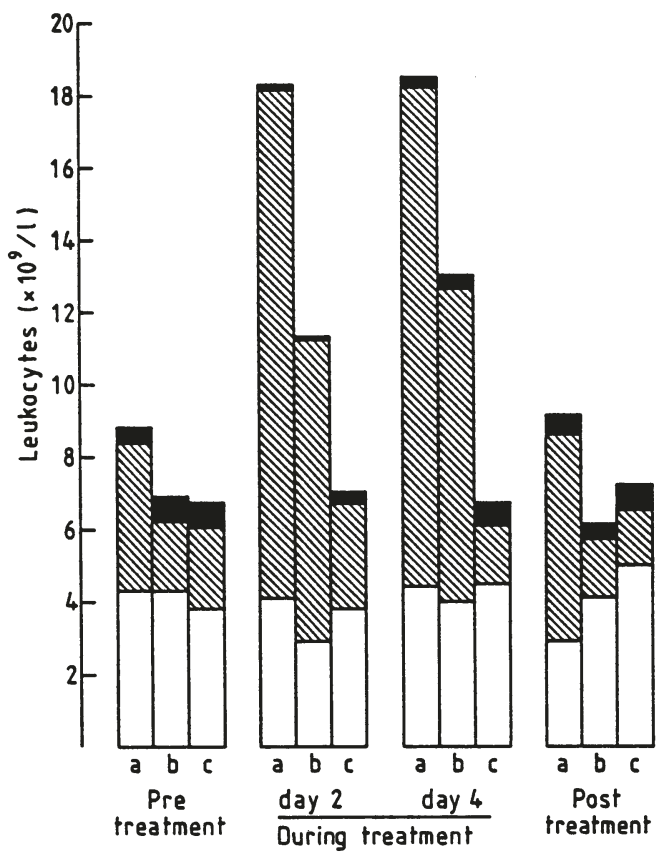

Figure 1. The number of leukocytes (total bar), neutrophils $(\mathbb{\mathbb { Q }})$, eosinophils $(\square)$ and mononuclear cells $(\square)$ before, during and after ACTH administration. The leukocytes were collected from 4 head of cattle persistently infected with bovine viral diarrhea virus (a), 3 controls (b) and 3 untreated controls (c).

\section{Mononuclear cell subpopulations}

The proportions of B cells, T cells, Fc $\gamma^{+}$cells and of monocytes were not significantly affected by ACTH treatment (Table 1).

Stimulatory response of lymphocytes to mitogens

The intensity of lymphocyte proliferation induced by mitogen stimulation was tested before, during and after ACTH treatment. Details are given in Fig. 2. Before ACTH treatment, lymphocytes from persistently BVDV-infected cattle responded with less intensity to Con A and to PWM stimulation than did lymphocytes from controls. 
Table 1. The mean proportions of $\mathrm{B}$ cells, $\mathrm{T}$ cells, $\mathrm{Fc} \gamma^{+}$cells and monocytes among blood mononuclear cells (MNC) before, during and after ACTH administration in cattle persistently infected with bovine viral diarrhea virus $(n=4)$, in controls $(n=3)$ and in untreated controls $(n=3)$.

\begin{tabular}{|c|c|c|c|c|c|c|c|c|c|c|c|c|}
\hline \multirow[b]{2}{*}{$\begin{array}{l}\text { Day of } \\
\text { ACTH } \\
\text { treatment }\end{array}$} & \multicolumn{3}{|c|}{ B cells $(\%)$} & \multicolumn{3}{|c|}{$\mathrm{T}$ cells $(\%)$} & \multicolumn{3}{|c|}{ Monocytes (\%) } & \multicolumn{3}{|c|}{ Fc $\gamma+$ cells $(\%)$} \\
\hline & $\begin{array}{c}\text { BVDV } \\
\text { in- } \\
\text { fected }\end{array}$ & $\begin{array}{l}\text { Con- } \\
\text { trols }\end{array}$ & $\begin{array}{c}\text { Un- } \\
\text { treated } \\
\text { controls }\end{array}$ & $\begin{array}{c}\text { BVDV } \\
\text { in- } \\
\text { fected }\end{array}$ & $\begin{array}{l}\text { Con- } \\
\text { trols }\end{array}$ & $\begin{array}{c}\text { Un- } \\
\text { treated } \\
\text { controls }\end{array}$ & $\begin{array}{l}\text { BVDV } \\
\text { in- } \\
\text { fected }\end{array}$ & $\begin{array}{l}\text { Con- } \\
\text { trols }\end{array}$ & $\begin{array}{c}\text { Un- } \\
\text { treated } \\
\text { controls }\end{array}$ & $\begin{array}{l}\text { BVDV } \\
\text { in- } \\
\text { fected }\end{array}$ & $\begin{array}{l}\text { Con- } \\
\text { trols }\end{array}$ & $\begin{array}{l}\text { Un- } \\
\text { treated } \\
\text { controls }\end{array}$ \\
\hline Before & 20.1 & 17.3 & 16.7 & 60.5 & 59.6 & 57.8 & 5.1 & 5.0 & 4.2 & 22.0 & 16.0 & 19.0 \\
\hline 2 & 18.5 & 16.7 & 16.0 & 62.0 & 59.0 & 58.3 & 7.0 & 4.7 & 3.0 & 23.2 & 16.3 & 20.6 \\
\hline 4 & 21.2 & 16.3 & 15.7 & 61.3 & 61.0 & 59.6 & 6.8 & 7.0 & 3.7 & 23.5 & 19.0 & 20.0 \\
\hline After & 21.0 & 16.7 & 15.7 & 60.3 & 60.0 & 61.3 & 4.0 & 4.6 & 3.7 & 22.0 & 18.0 & 18.7 \\
\hline
\end{tabular}

The effect of ACTH administration on lymphocyte stimulation was evaluated by calculating the percentage alteration of $\mathrm{cpm}$ values in comparison with the pretreatment data. ACTH treatment did not affect the proliferation of lymphocytes in cultures without mitogen. However, the mitogen-induced lymphocyte stimulation was significantly suppressed during ATCH treatment, both in cultures of lymphocytes obtained from control animals (Con A: day 2 and day 4, p<0.01; PWM: day 2 and day 4, p<0.05) and from persistently BVDV-infected cattle (Con A: day 2 and day 4, p <0.001; PWM: day $2, \mathrm{p}<0.01$, day 4 , not significant). The cpm values obtained 2 days after completion of ACTH treatment were close to the preteatment values.

The mitogenic responses of lymphocytes from untreated controls were in the same range throughout the period.

\section{Discussion}

One expression of the body's general response to external stress is the release of ACTH from the pituitary gland, which stimulates the adrenal cortex to increase the secretion of cortisol. High concentrations of cortisol are associated with suppression of the immune response and increased susceptibility of the animal to infections (for review see Roth 1985). Shope et al. (1976) reported that ad-
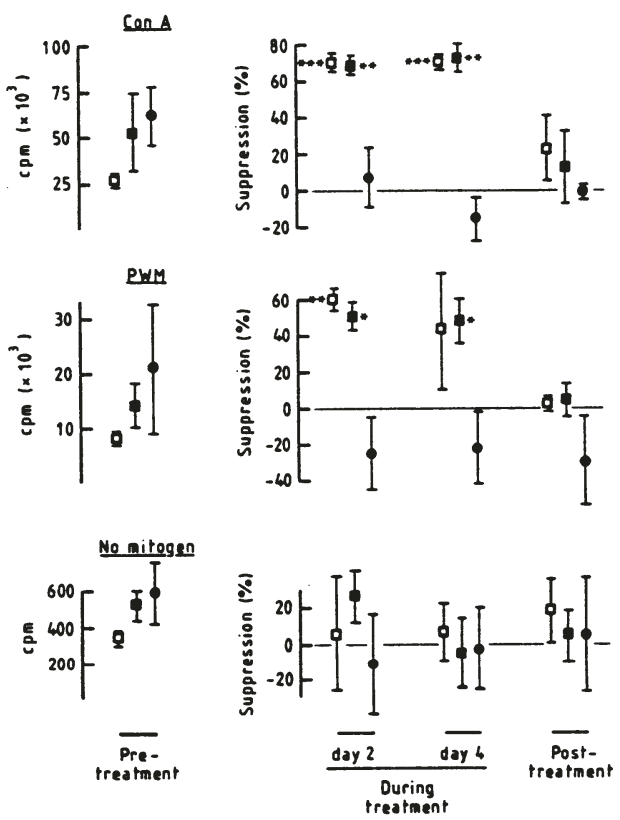

Figure 2. The suppressive effect of ACTH administration on the proliferation of mononuclear cells (MNC). The MNC were collected from 4 head of cattle persistently infected with bovine viral diarrhea virus ( $\square$ ), 3 controls $(\square)$ and 3 untreated controls $(\bullet)$. The stimulatory responses of MNC to pokeweed mitogen (PWM) and to Concanavalin A (Con A) before ACTH administration are expressed as counts per min (cpm) and during and after ACTH administration as percentage suppression vs. pretreatment data. Data are expressed as means \pm S.E.M. Significant suppression is indicated by $*(p<0.05)$, ** $(p<0.01)$ and ${ }^{* * *}(p<0.001)$. 
ministration of large doses of dexamethasone before and after BVDV inoculation of seronegative calves induced a disease similar to MD, but it was not stated whether the calves were initially free from BVDV infection or not. In the present study, administration of ACTH resulted in a 20 -fold increase in $\mathbf{P}$ cortisol, but none of the persistently BVDVinfected animals showed any clinical sign of disease throughout the observation period of 1 month or longer.

Treatment with ACTH induced the expected alterations in total and differential leukocyte counts. In both groups of animals there was a doubling of the number of leukocytes, a three-fold increase in the number of neutrophils and a 50\% reduction in the number of eosinophils- changes which have been reported earlier to result from ACTH injections (Paape et al. 1977, Gwazdauskas et al. 1980, Roth et al. 1982).

The number of MNC in blood did not alter during ACTH administration which is in agreement with results published by other authors (Paape et al. 1977, Roth et al. 1982). However, the function of MNC was reduced during ACTH treatment, as indicated by a significantly suppressed mitogen-induced proliferation of lymphocytes, both in BVDV-infected cattle and in control animals (Fig. 2). Similarly, administration of ACTH to cattle has earlier been shown to suppress the lymphocyte proliferation induced by Con A, PWM and by phytohemagglutinin (Roth et al. 1982). The exact mechanisms by which ACTH administration depresses lymphocyte proliferation in cattle is not fully understood. It may be attributable to an inhibited production of interleukin 2 by MNC (Blencha \& Baker 1986), to a direct inhibitory effect of cortisol on mitosis, or to a redistribution of a subpopulation of MNC having regulatory functions to the extravascular compartment (Parrillo \& Fauci 1979). As regards regulatory cells, bovine monocytes have been shown to have enhancer properties in lymphocyte stimulation tests (Mastro \& Sniezek 1983/1984) whereas bovine Fc $\gamma^{+}$ cells have suppressor activity in the same test (Fossum et al. 1985). The suppressive effect of $\mathrm{Fcy}{ }^{+}$cells is more pronounced in persistently BVDV-infected cattle than in controls (Larsson, 1988). However, the numbers of monocytes and of $\mathrm{Fc} \gamma^{+}$cells as well as of $B$ and $T$ cells were not significantly influenced by administration of ACTH. Thus, the mutual proportions of the subpopulations tested in this study could not account for the weakened response of lymphocytes to mitogen stimulation.

In conclusion, administration of ACTH during a 5-day period to 4 cattle persistently infected with BVDV did not elicit any clinical symptoms of MD. This finding does not exclude the possibility that stress might be involved in the pathogenesis of MD. Administration of ACTH had the same effect in the BVDV-infected cattle as in the control animals, i.e., it elicited increased P-cortisol levels, reduced the response of lymphocytes to mitogen stimulation, and produced leukocytosis and neutrophilia, but the numbers of MNC as well as the proportions of B cells, $T$ cells, $\mathrm{Fc} \gamma^{+}$cells and monocytes remained unaltered.

\section{Acknowledgements}

The author wishes to thank Dr. C. Fossum, Prof. S.O. Jacobsson and Dr. S. Alenius for stimulating discussions and for helpful criticism. This work was supported by grants from the Swedish Council for Forestry and Agricultural Research.

\section{References}

Blencha F, Baker PE: Effect of cortisol in vitro and in vivo on production of bovine interleukin 2 . Amer. J. vet. Res. 1986, 47, 841-845. 
Bolin SR, McClurkin AW, Cultip RC, Coria MF: Severe clinical disease induced in cattle persistently infected with noncytopathic bovine viral diarrhea virus by superinfection with cytopathic bovine viral diarrhea virus. Amer. J. vet. Res. 1985, 46, 573-576.

Brownlie J, Clarke MC, Howard CJ: Experimental production of fatal mucosal disease in cattle. Vet. Rec. 1984, 114, 535-536.

Brownlie J, Clarke MC, Howard CJ, Popock DH: Mucosal disease: the dilemma of experimental disease. In Proc. 14th World Congress on Diseases of Cattle. ed P. J. Hartigan \& M. L. Monaghan. World Association for Buiatrics, Dublin 1986, pp. 199-203.

Bøyum A: Isolation of leukocytes from human blood. A two phase system for removal of red cells with methyl cellulose as erythrocyte aggregating agent. Scand. J. clin. lab. Invest. 1968, 21, suppl. 9, 4-29.

Fossum $C$, Bergman $R$, Morein B: Suppressor activity of bovine $\mathrm{Fc} \gamma$ positive cells during a persistent infection with Mycobacterium avium. Res. Vet. Sci. 1985, 38, 270-274.

Gwazdauskas FC, Paape MJ, Peery DA, McGillard $M L:$ Plasma glucocorticoid and circulating blood leukocyte responses in cattle after sequential intramuscular injections of ACTH. Amer. J. vet. Res. 1980, 41, 1052-1056.

Johansson C, Morein B: Evaluation of labelling methods for bovine T and B lymphocytes. Vet. Immunol. Immunopathol. 1983, 4, 345-359.

Johnson $K$, Morein B: In vitro stimulation of bovine circulating lymphocytes by parainfluenza type 3 virus. Res. Vet. Sci. 1977, 22, 83-85.

Juntti N, Larsson B, Fossum C: The use of monoclonal antibodies in enzyme-linked immunosorbent assays for detection of antibodies to bovine viral diarrhea virus. J. Vet. Med. B. 1987, 34, 356-363.

Larsson B: Increased suppressor cell activity in cattle persistently infected with bovine viral diarrhea virus. J. Vet. Med. B. 1988, 35, 271-279.

Larsson B, Fossum C, Alenius $S$ : A cellular analysis of immunosuppression in cattle with mucosal disease. Res. Vet. Sci. 1988, 44, 71-75.

Liess B, Frey H-R, Kittsteiner H, Baumann F, Neumann $W$ : Beobachtungen und Untersuchungen über die »Mucosal Disease« des Rindes - einer immunbiologisch erklärbaren spätform der BVD-MD-virusinfektion mit kriterien einer "Slow virus infection" (Observations and investigations on Mucosal Disease of cattle, a late stage of BVD-MD virus infection with immunbiologic explanation and criteria of a slow virus infection?). Dtsch. Tierärztl. Wschr. 1974, 81, 477 500.

Malmquist WA: Bovine viral diarrhea - mucosal disease: etiology, pathogenesis, and applied immunity. J. Amer. vet. med. Assoc. 1968, 152, 763768.

Mastro AM, Sniezek MJ: The effect of removal of adherent cells in lectin and allogenic cell stimulation of bovine lymphocytes. Vet. Immunol. Immunopathol. 1983/1984, 5, 161-176.

Matsson P, Fossum C, Larsson B: Evaluation of flow cytometry and fluorescence microscopy for the estimation of bovine mononuclear phagocytes. J. immunol. Meth. 1985, 78, 13-24.

Nyberg L, Lundström K, Edfors-Lilja I, Rundgren $M$ : Effets of transport stress on concentrations of cortisol, corticosteroid-binding globulin and glucocorticoid receptor in pigs with different halothane genotypes. J. Anim. Sci. 1988, 66, 12011211.

Olafson P, MacCallum AD, Fox FH: An apparently new transmissible disease of cattle. Cornell. Vet. 1946, 36, 205-213.

Paape MJ, Desjardins C, Guidry AJ, Miller RH, Smith VR: Response of plasma corticosteroids and circulating leukocytes in cattle following intravenous injection of different doses of adrenocorticotropin. Amer. J. vet. Res. 1977, 38, 1345 1348.

Parrillo, JE, Fauci AS: Mechanisms of glucocorticoid action on immune processes. Ann. Rev. Pharmacol. Toxicol. 1979, 19, 179-201.

Ramsey FK, Chivers WH: Mucosal disease of cattle. North Am. Vet. 1953, 34, 629-633.

Roeder PL, Drew TW: Mucosal disease of cattle: A late sequel to fetal infection. Vet. Rec. 1984, 114, 309-313.

Roth JA, Kaeberle ML, Hsu WH: Effects of ACTH administration on bovine polymorphonuclear leukocyte function and lymphocyte blastogenesis. Amer. J. vet. Res. 1982, 43, 412-416. 
Roth JA: Cortisol as a mediator of stress-associated immunosuppression in cattle. In: Animal Stress. ed. G. P. Moberg, Am. Physiological Society. Bethesda, USA 1985, pp. 225-243.

Roth JA, Bolin SR, Frank DE: Lymphocyte blastogenesis and neutrophil function in cattle persistently infected with bovine viral diarrhea virus. Amer. J. vet. Res. 1986, 47, 1139-1141.

Shope RE, Muscoplat CC, Chen AW, Johnson DW: Mechanism of protection from primary bovine viral diarrhea infection. I. The effects of dexamethasone. Can. J. comp. Med. 1976, 40, 355-359.

Steck F, Lazary S, Fey H, Wandeler A, Huggler $C$, Oppliger G, Baumberger H, Kaderli R, Martig J: Immune responsiveness in cattle fatally affected by bovine viral diarrhea - mucosal disease. $\mathrm{Zbl}$. Vet. Med. B. 1980, 27, 429-445.

\section{Sammanfattning}

Försök att framkalla mucosal disease hos nötkreatur persistent infekterade med bovint virusdiarré virus genom injektioner med adrenocorticotropt hormon. Senare års forskning har visat att nötkreatur som utvecklar mucosal disease (MD) ofta har varit kroniskt infekterade med bovint virusdiarré virus (BVDV) sedan födelsen. Syftet med denna studie var att under- söka om en immunsuppression av persistent BVDV infekterade djur kan framkalla MD. Av detta skäl injicerades 4 kroniskt infekterade djur och 3 kontroller med adrenocortiocotropt hormon (ACTH) 2 gånger dagligen i 5 dagar. Före ACTH behandlingen var antalet leukocyter, neutrofiler och mononukleära celler (MNC) per liter blod hos kroniskt BVDV infekterade djur på samma nivå som hos kontrolldjuren. Även proportionerna B celler, T celler, monocyter och Fc $\gamma^{+}$celler (celler med receptor för Fc delen av IgG) var lika i de bảda grupperna. Däremot svarade lymfocyter från kroniskt BVDV infekterade djur sämre på mitogenstimulering än vad lymfocyter från kontrolldjuren gjorde.

Alla djur svarade på ACTH behandling med stegrade cortisol värden i plasma, leukocytos, neutrofili och en minskad mitogen inducerad lymfocytproliferation. Antalet MNC och proportionerna av B celler, $\mathrm{T}$ celler, $\mathrm{Fc} \gamma^{+}$celler och mononcyter förblev oförändrade under ACTH behandling. Trots den observerade immunosuppressionen, indikerad av den minskade benägenheten av lymfocyterna att svara på mitogen stimulering, framkallade ACTH behandling inga symtom på MD hos kroniskt BVDV infekterade djur.

(Received July 16, 1987).

Reprints may be requested from: Bengt Larsson, Department of Cattle and Sheep Diseases, Veterinary College, Swedish University of Agricultural Sciences, Box 7019, S-750 07 Uppsala, Sweden. 